DOI: $10.37317 /$ pbss-2019-0003

M. A. Dorri ${ }^{1}$, B. $\operatorname{Kamkar}^{2}$, M. Aghdasi ${ }^{3}$, A. R. Safahani ${ }^{4 *}$

${ }^{1}$ Agricultural and Natural Resources Research and Education Center of Golestan, Gorgan, Iran;

${ }^{2}$ Dept. of Agronomy, Gorgan University of Agricultural Sciences and Natural Resources, Gorgan, Iran; ${ }^{3}$ Dept. of Biology, Golestan University, Gorgan, Iran; ${ }^{4}$ Agronomy Department, Payame Noor University, 19395-4697 Tehran, I. R. of IRAN.

*Corresponding Author: safahani_ali@yahoo.com

\title{
GERMINATION AND SEEDLING GROWTH OF SILYBUM MARIANUM AS A MEDICINAL PLANT UNDER SALINITY STRESS
}

\begin{abstract}
Milk thistle (Silybum marianum) is used as a medicinal plant in the treatment of liver diseases. In order to investigate germination and seedling growth in $\mathrm{S}$. marianum subjected to $\mathrm{NaCl}$, a three replicated experiment was carried out in a randomized complete block design in the laboratory of Gorgan University of Agricultural Sciences and Natural Resources. Treatments included seven salinity levels $(50,75,100,125,150,175$ and $200 \mathrm{mM}$ ) and a control (distilled water). Germination percentage (GP), mean germination time (MGT), seedling vigour index (SVI), shoot, root and seedling weight were measured. The effect of salinity levels was significant on GP, SVI, MGT and seedling weight and length $(\mathrm{p} \leq 0.01)$. However, the $\mathrm{NaCl}$ concentration effect was not significant on shoot : root length ratio and or shoot : root weight ratios. Results showed that germination decreased when salinity increased, while MGT increased. MGT was 1.75 times higher than in the control at the highest salt concentration. MGT difference was not significant between $75 \mathrm{mM} \mathrm{NaCl}$ and control, while it dramatically increased by increasing the $\mathrm{NaCl}$ concentration from 150 to $200 \mathrm{mM} \mathrm{NaCl}$. Reduction slope and salt tolerance index (STI) were estimated for germination (0.54 and 231.9) and seedling stage (0.24 and 237.4). According to the results, milk thistle could be considered as a valuable medicinal plant in fairly salinized areas.
\end{abstract}

Key words: germination, medicinal plant, $\mathrm{NaCl}$, Silybum marianum.

\section{INTRODUCTION}

Chaudhary et al. (2010) reported that milk thistle was one of the top ten bestselling medicinal plants in 2007 worldwide. Silybum marianum, commonly known as milk thistle, belongs to a family Asteraceae and is one of the oldest and thoroughly researched plants in the treatment of liver diseases (Pradhan and

Communicated by Grzegorz Żurek 
Girish, 2006). The dried seeds include four flavonolignans that are collectively known as silymarin. Silymarin is extracted from the dried seeds where it is present in higher concentrations than in other parts of the milk thistle plant (Luper, 1998).

Salinization of soil and water is one of the world's most serious agricultural environmental problems. Salinity of soil or water is one of major stress obstacles for plant growing areas globally; especially in arid and semi-arid regions, these conditions can severely limit plant production (Jamil et al., 2006). Some areas affected by salinity and salt experience a steady increase; however, statistical data show that these regions include almost $50 \%$ of the world's fields, which is equal to three times more than under- cultivation areas (Kamkar et al., 2004). These results were due to the effect of salinity stress on quantitative and qualitative parameters. For instance, it was found that increasing salinity stress decreased almost all of growth parameters in Nigella sativa, as well as some growth parameters and essential oil amounts in chamomile (Razmjoo et al., 2008).

Germination is one of the most salt-sensitive plant growth stages and can therefore be severely inhibited by increased salinity (Sosa et al., 2005; Ghavami and Ramin, 2007). The negative responses of seed germination under salt stress has been reported by many authors regarding Ocimum basilicum, Eruca sativa, Petroselinum hortense, chamomile, sweet marjoram and Thymus maroccanus (Miceli et al., 2003; Belaqziz et al., 2009). Ahmadian et al., (2012) showed that germination decreased from $79.76 \%$ to $50.2 \%$ as a result of salt concentration increasing. Salinity delays the onset, reduces the rate and increases the dispersion of germination events, leads to reduced plant growth and final crop yield (Ashraf and Foolad, 2005).

Salinity caused a significant reduction in seedling growth of Thymus maroccanus (Belaqziz et al., 2009). Salinity affects seedling growth through slower or less mobilization of reserve foods, suspending cell division and enlarging and injuring hypocotyls (Rahman et al., 2008). Reduced seedling growth has also been reported for basil, chamomile and marjoram (Ramin, 2005; Ali et al., 2007; Baatour et al., 2010). Ghaderi-Far et al. (2012) reported that milk thistle was sensitive to salinity in the germination stage, but was moderately saline tolerant in the seedling stage. Growth parameters such as plant height, number of leaves per plant and number of capitula per plant on milk thistle were reduced in the instance of a salinity level greater than $9 \mathrm{dS} \mathrm{m}^{-1}$ (Ghavami and Ramin, 2008). Comparison of root- to shoot-length ratio for Calendula officinalis under salinity levels showed that this ratio decreased in all of the treatments when compared to the control (Torbaghan et al., 2012).

Due to the increasing demand for medicinal plants and traditional medical systems worldwide (including within the pharmaceutical industry), some medicinal plants need to be grown commercially; however, soil salinity and other forms of pollution pose serious threats to crop production (Qureshi et al., 2005).

The increasing attention paid to the health concerns regarding the hazards of synthetic drugs has given rise to an increased interested in plant-based drugs. In order to produce medicinal plants for the pharmaceutical industry, these plants 
need to be cultivated commercially, especially in marginal and low quality lands. One of the most effective ways to overcome salinity problems is the introduction of salt tolerant crops) Yildirim et al., 2011).

The aim of this study was to evaluate the seed germination and seedling growth response of milk thistle as a medicinal plant exposed to salinity, which its results may be used for decision making about its cultivation where may be lower utilized in agriculture. The findings of this study hopes to contribute to the better utilization of saline habitats.

\section{MATERIAL AND METHODS}

The experiment was carried out using a three-replicated randomized complete block design using seven salinity levels $(50,75,100,125,150,175$ and $200 \mathrm{mM}$ ) and a control in the Agricultural Sciences and Natural Resources seed research laboratory of Gorgan University of Agricultural Sciences and Natural Resources in 2012. Each experimental unit consisted of a petri dish $(15 \mathrm{~cm}$ diameter) in which 50 Silybum marianum seeds were placed on top of two sheets of filter paper and covered by a single sheet of filter paper. The seeds were disinfected with $1 \% \mathrm{NaOCl}$ and rinsed with running tap water three times prior to the germination test. Petri dishes were supplied with $10 \mathrm{ml}$ of each treatment solution and distilled water for the control treatment. Finally, Petri dishes were covered with a polyethylene sheet to avoid the loss of moisture through evaporation. The temperature was adjusted to a constant of $20^{\circ} \mathrm{C}$.

\section{Germination percentage}

The germination period was started 48 hours after the experiment onset and continued until the $14^{\text {th }}$ day. The criterion for germination was radical emergence of two millimetres or more. The germination period was stopped when no seeds germinated within a period of 48 hours, or when all the seeds had germinated. Each time the germinated seeds were counted, the exact time of counting was recorded. Final germination percentage (GP) was calculated using formula of Elouaer and Hannachi, 2012:

$$
G P=\sum_{i=0}^{n} \frac{N_{i} \times 100}{N}
$$

where, $N i$ - number of germinated seeds up to day i and $N$ - the total number of seeds. Mean germination time (MGT) for individual replicates was also calculated on the basis of Ellis and Roberts formula, (1981)

$$
M G T=\frac{\sum_{i=0}^{n} T_{i} \times N_{i}}{F}
$$

where $T i, N i$ and $F$ were the days on which the germination count was made, the number of seeds germinated on the counting day and the final number of germinated seeds in each replication, respectively. 
Germination percentage data were arcsine transformed. Data were subjected to ANOVA procedures and means were separated using the least significant difference (LSD) test at a 5\% probability level.

\section{Seedling vigour index}

Seedling vigour index (SVI) was calculated following a modified equation (Islam et al., 2009)

$$
S V I=\frac{S L \times G P}{100}
$$

At the end of the experiment, 10 seedlings were selected from each Petri dish. Then, seedling shoots and root fresh weights, as well as their lengths were recorded, and were oven dried at $75^{\circ} \mathrm{C}$ for 24 hours to measure seedling shoot and root dry weight.

\section{Salt tolerance evaluation}

Salt tolerance was assessed as the amount of salinity that caused $50 \%$ inhibition of germination. A three-parameter logistic model (Chauhan et al., 2006; Tanveer et al., 2013) was fitted to seed germination percentages obtained at different concentrations of $\mathrm{NaCl}$ using Sigma Plot software (v. 11).

$$
G P=\frac{a}{\left(1+C / C_{50}\right)^{S C_{50}}}
$$

where, GP: total germination (\%) at $\mathrm{NaCl}$ concentration levels; a: maximum germination percentage seen at control; $\mathrm{C}$ : the electrical conductivity in $\mathrm{dSm}^{-1}$; $C_{50}$ : defined $C$ at $G r=0.5$, which was $50 \%$ of total germination in a potential condition; $S$ : represented the response curve steepness.

Salt tolerance index (STI) was also used to evaluate salt tolerance (Steppuhn et al., 2005)

$$
S T I=C_{50}+S C_{50}
$$

C50 and $S$ parameters were estimated using the NLIN and REG procedures (SAS 9.1, Institute Inc., 1988).

Salinity response threshold for germination and seedling weight was also obtained based on the linear response equation proposed by Maas - Hoffman (1977):

$$
Y_{r}=100-b \times\left(E_{c}-a\right)
$$

where $a$ is salinity tolerance threshold corresponding to the salinity value of $E_{C}$, beyond which a reduction in yield starts appearing with respect to nonsaline conditions and $b$ is the rate of decrease (slope) in $Y$ by unit increase of $E_{C}$. 
Germination and seedling growth of S.marianum as a medical plant under salnity... 29

\section{RESULTS}

Salinity effects were significant in terms of seed germination percentage, seedling vigour and MGT $(\mathrm{p} \leq 0.01$, but not significant for both $\mathrm{S}: \mathrm{R}$ length ratios and $\mathrm{S}: \mathrm{R}$ weight ratios (Table 1 ).

The results revealed that the seed germination (\%) of milk thistle was affected by an increase in NaCI concentration (Table 1).

Table 1

Mean squares of measured traits in germination and seedling stage: Germination percentage (GP), Mean germination time (MGT), Seedling vigour index (SVI)

\begin{tabular}{|c|c|c|c|c|c|c|c|c|}
\hline \multirow{2}{*}{ S.O.V } & \multirow{2}{*}{ DF } & \multirow{2}{*}{ GP } & \multirow{2}{*}{ MGT } & \multicolumn{2}{|c|}{ Seedling } & \multicolumn{2}{|c|}{$\mathrm{S}: \mathrm{R}$ ratio } & \multirow{2}{*}{ SVI } \\
\hline & & & & Length & Weight & Length & Weight & \\
\hline Rep & 2 & 8.76 & 0.019 & 0.86 & 0.021 & 1.43 & 0.022 & 0.79 \\
\hline $\mathrm{NaCl}$ Con. & 7 & $232.97^{* *}$ & $1.55^{* *}$ & $5.72^{* *}$ & $7.25^{* *}$ & $1.06^{\mathrm{ns}}$ & $0.15^{\mathrm{ns}}$ & $10.35^{* *}$ \\
\hline Error & 14 & 6.78 & 0.197 & 0.249 & 0.403 & 0.501 & 0.097 & 0.248 \\
\hline CV.\% & & 4.34 & 12.11 & 6.13 & 5.42 & 14.73 & 7.09 & 8.04 \\
\hline
\end{tabular}

**: significant at 0.01 level and ns: no significant

The reduction of germination percentage was observed mainly at the higher levels of $\mathrm{NaCI}$ concentration compared to the control, as the lowest germination percentage was related to the highest salinity level $(200 \mathrm{mM})$, where only $42.7 \%$ of the seeds were germinated (Table 2 ).

Table 2

Mean comparisons of germination percentage (GP), Mean Germination Time (MGT) and seedling vigor index (SVI) for milk thistle seeds under different salinity levels

\begin{tabular}{cccccc}
\hline $\begin{array}{c}\mathrm{NaCl} \mathrm{Conc.} \\
{[\mathrm{mM}]}\end{array}$ & $\begin{array}{c}\mathrm{GP} \\
{[\%]}\end{array}$ & $\begin{array}{c}\text { Length } \\
{[\mathrm{cm}]}\end{array}$ & $\begin{array}{c}\text { Weight } \\
{[\mathrm{mg}]}\end{array}$ & $\begin{array}{c}\text { MGT } \\
{[\mathrm{h}]}\end{array}$ & SVI \\
\cline { 3 - 5 } & $81.33 \mathrm{a}$ & $9.66 \mathrm{a}$ & $13.87 \mathrm{a}$ & $67.68 \mathrm{~d}$ & $7.84 \mathrm{ab}$ \\
50 & $83.3 \mathrm{a}$ & $10.08 \mathrm{a}$ & $13.00 \mathrm{a}$ & $70.32 \mathrm{~d}$ & $8.39 \mathrm{a}$ \\
75 & $79.4 \mathrm{a}$ & $9.48 \mathrm{a}$ & $13.27 \mathrm{a}$ & $74.88 \mathrm{~cd}$ & $7.52 \mathrm{~b}$ \\
100 & $82,0 \mathrm{a}$ & $7.11 \mathrm{bc}$ & $11.67 \mathrm{~b}$ & $84.96 \mathrm{bc}$ & $5.84 \mathrm{~cd}$ \\
125 & $83.3 \mathrm{a}$ & $7.90 \mathrm{bc}$ & $11.20 \mathrm{bc}$ & $89.28 \mathrm{bc}$ & $6.58 \mathrm{c}$ \\
150 & $77 \mathrm{a}$ & $7.35 \mathrm{bc}$ & $10.73 \mathrm{bc}$ & $96.24 \mathrm{~b}$ & $5.70 \mathrm{~d}$ \\
175 & $64 \mathrm{~b}$ & $6.81 \mathrm{c}$ & $10.50 \mathrm{c}$ & $102.96 \mathrm{ab}$ & $4.36 \mathrm{e}$ \\
200 & $42.7 \mathrm{c}$ & $6.74 \mathrm{c}$ & $9.37 \mathrm{~d}$ & $117.84 \mathrm{a}$ & $2.88 \mathrm{f}$ \\
\hline
\end{tabular}

Means with at least one the same letter are not statistically different

Seedling weight of milk thistle was more pronounced compared to seedling length as a result of increasing $\mathrm{NaCl}$ concentration (determination coefficients of 0.84 and 0.68 , respectively) (Table 3 ). 
Table 3

Linear regression between $\mathrm{NaCl}$ concentration $(\mathrm{X})$ against shoot, root and seedling length $(\mathrm{Y})$

\begin{tabular}{lcccc}
\hline $\begin{array}{c}\text { Length } \\
(\mathrm{Y})\end{array}$ & $\begin{array}{c}\text { Intercept } \\
\text { (a) }\end{array}$ & $\begin{array}{c}\mathrm{B} \\
(\mathrm{X})\end{array}$ & $\mathrm{R}^{2}$ & $\begin{array}{c}\mathrm{CV} \\
{[\%]}\end{array}$ \\
\hline Shoot & 3.11 & -0.0093 & $0.52^{* *}$ & 28 \\
Root & 7.02 & -0.0088 & $0.48^{* *}$ & 9.8 \\
Seedling & 10.13 & -0.0182 & $0.68^{* *}$ & 9.8 \\
Seedling weight & 14.17 & -0.022 & $0.84^{* *}$ & 5.3 \\
\hline
\end{tabular}

**: significant at 0.01 of probability level

Linear regressions are shown for MGT and SVI vs. $\mathrm{NaCl}$ in Fig. 4a-b; root, shoot and seedling weight in Fig. 3a-b and for root, shoot and seedling length in Table 3.

A

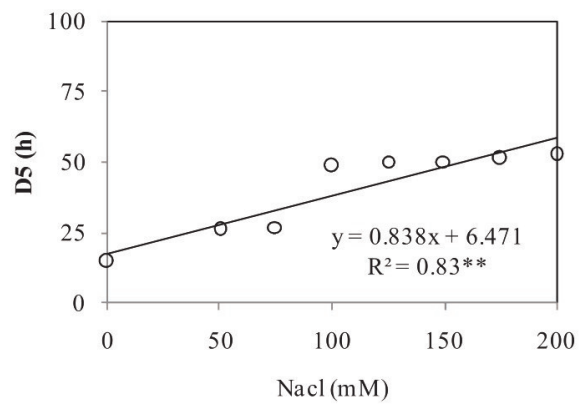

C

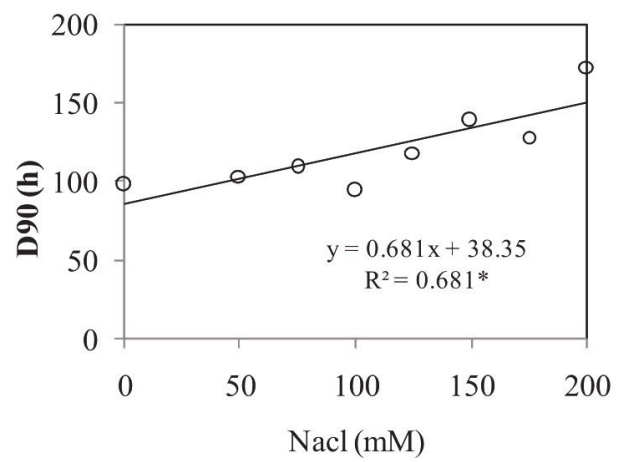

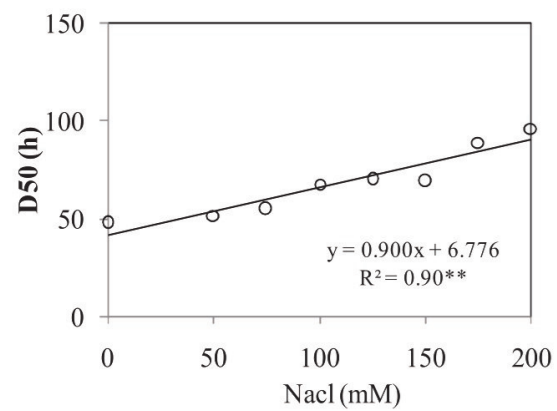

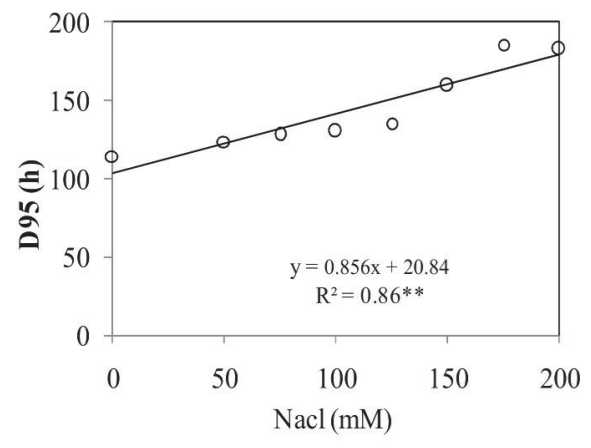

Fig. 1. A linear model fitted for $\mathrm{D}_{5}(\mathrm{~A}), \mathrm{D}_{50}(\mathrm{~B}), \mathrm{D}_{90}(\mathrm{C})$ and $\mathrm{D}_{95}(\mathrm{D})$ vs. $\mathrm{NaCl}$ concentration (mM)

Germination percentage difference was not significant in the control up to $150 \mathrm{mM}$ concentration (Table 2), but a reduction threshold was seen at 101.2 $\mathrm{mM}$ using the linear response equation from this threshold onward, germination percentage declined (Table 4). 
Germination and seedling growth of S.marianum as a medical plant under salnity... 31

Threshold, slope, C50 and STI for seed germination percentage

Table 4 and seedling weight of $S$. marianum vs. $\mathrm{NaCl}$

\begin{tabular}{|c|c|c|c|c|c|c|}
\hline Equation & $\begin{array}{l}\text { Threshold } \\
{[\mathrm{mM}]}\end{array}$ & Slope & $\begin{array}{c}\mathrm{C}_{50} \\
{[\mathrm{mM}]}\end{array}$ & $\mathrm{SC}_{50}$ & STI & Significant \\
\hline$G_{p}=G_{\max } / 1+\left(e c / C_{50}\right)^{S C_{50}}$ & - & - & 231.4 & 0.52 & 231.92 & $* *$ \\
\hline$G_{r}=100-b \times(e c-a)$ & 101.2 & 0.54 & - & - & - & $* *$ \\
\hline Yield $=Y_{m} / 1+\left(e c / C_{50}\right)^{S C_{50}}$ & - & - & 234.8 & 2.58 & 237.38 & $* *$ \\
\hline$Y_{r}=100-b \times(e c-a)$ & 43.64 & 0.247 & - & - & - & $* *$ \\
\hline
\end{tabular}

To clarify germination onset times, D5, 50, 90 and $95 \%$ of maximum germination percentage, a linear model was fitted against $\mathrm{NaCl}$ concentrations (Figs. 1a-d). This model showed that D5 (time to 5\% of maximum germination), D50 (time to $50 \%$ of maximum germination), D90 (time to $90 \%$ of maximum germination) and D95 (time to $95 \%$ of maximum germination) were strongly related to salinity levels (Figs 1a-d).

Germination was started in the control at the shortest time, while this time in $50 \mathrm{mM}$ and $75 \mathrm{mM} \mathrm{NaCl}$ was 1.7 times longer than the control and in other concentrations increased more than three times compared to the control which obviously occurred at concentration $200 \mathrm{mM}$ (Fig. 2).

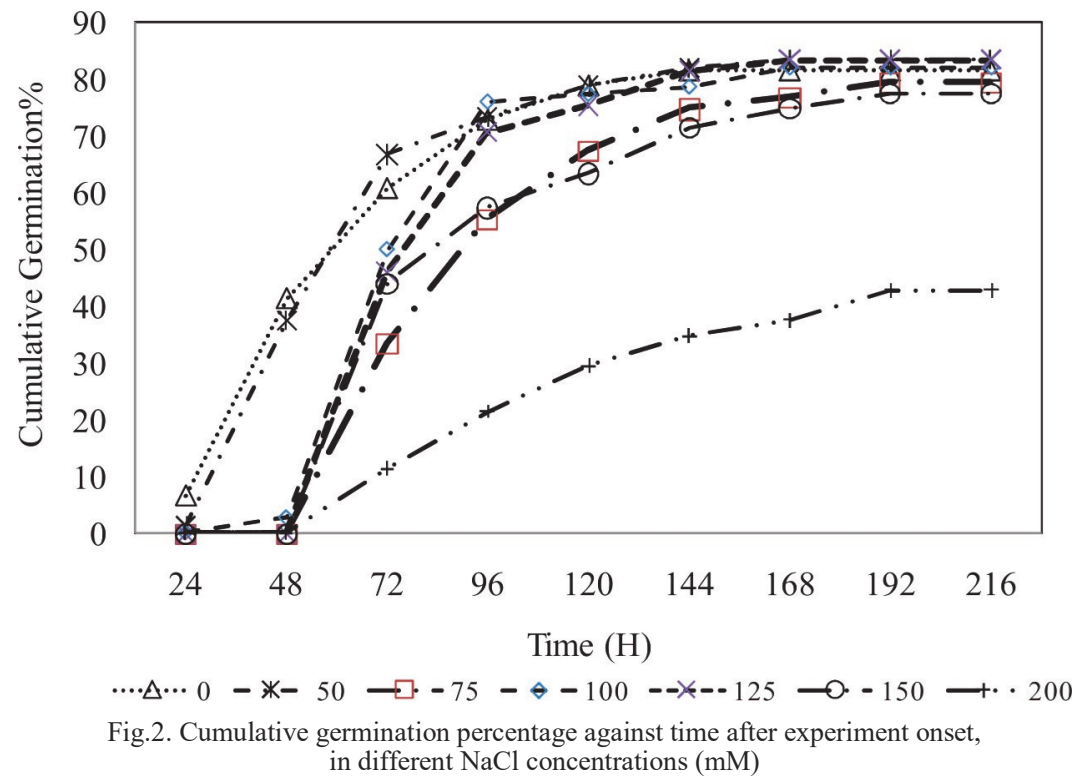

Similarly, D50, D90 and D95 were shorter in the control (Figs. 1b-d). As $\mathrm{NaCl}$ concentration increased, D50, D90 and D95 also increased. D50 in 100 and $125 \mathrm{mM} \mathrm{NaCl}$ was delayed 1.4 times longer than the control while it was longer in 175 and $200 \mathrm{mM} \mathrm{NaCl}$ so that it was recorded 1.86 and 2.02 times longer than the control, respectively (Fig. 1b). 
MGT difference was not significant between $75 \mathrm{mM} \mathrm{NaCl}$ and control, while above $75 \mathrm{mM} \mathrm{NaCl}$ was significant differences so that MGT dramatically increased by increasing the $\mathrm{NaCl}$ concentration from 150 to $200 \mathrm{mM}$ $\mathrm{NaCl}$ (Table 2).

SVI in salinity levels of 50 and $75 \mathrm{mM}$ were not significantly different from the control, while it decreased at $200 \mathrm{mM}$ to $63.26 \%$ and $65.67 \%$ compared to the control, and $50 \mathrm{mM}$ salinity levels, respectively (Table 2).

Mean comparisons showed that there were significant differences between seedlings' length and weight means at a higher than $75 \mathrm{mM}$ salinity level compared to the control (Table 2). Our results showed that $\mathrm{NaCl}$ concentration caused more inhibition in shoot growth than in root growth (Fig. 3). Therefore, shoot/root dry weight ratio decreased by increasing $\mathrm{NaCl}$

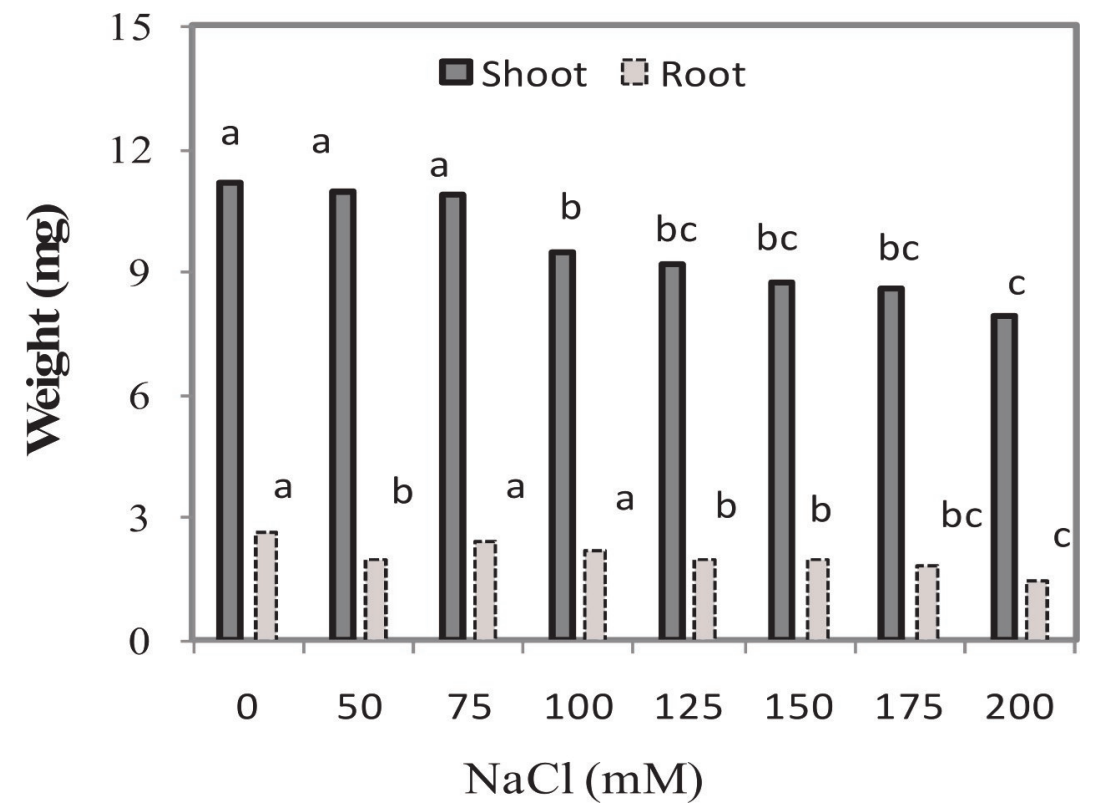

levels.

Fig.2. Cumulative germination percentage against time after experiment onset, in different $\mathrm{NaCl}$ concentrations $(\mathrm{mM})$

A slight increase $\left(0.01\right.$ hour per $\left.1 \mathrm{ds} \times \mathrm{m}^{-1}, \mathrm{R}^{2}=0.74\right)$ was observed in MGT by increasing $\mathrm{NaCl}$ concentration (Fig. $4 \mathrm{a}$ ), so that MGT was 1.38 and 1.7 times more than the control at $150 \mathrm{mM}$ and at $200 \mathrm{mM}$, respectively (Table 2). SVI also had a negative slope of -0.025 and $\mathrm{R}^{2}=0.82$ when regressed against $\mathrm{NaCl}$ concentrations and a drastic reduction appeared at $200 \mathrm{mM}$ compared to the control (Fig. 4b).

A three-parameter logistic model was fitted seed germination percentage against seedling weight of milk thistle data and salinity levels (Fig. 5a-b). According to the model, the salinity response threshold of seed germination and seedling stage in milk thistle were estimated as $101.2 \mathrm{mM}$ and $43.6 \mathrm{mM}$, respectively (Table 4, Fig. 5a-b). 


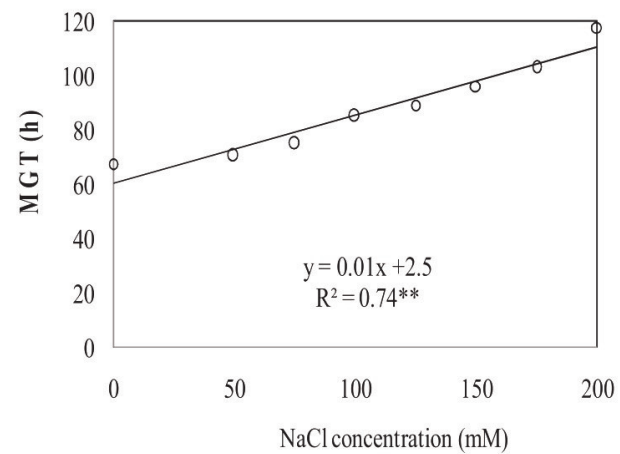

B

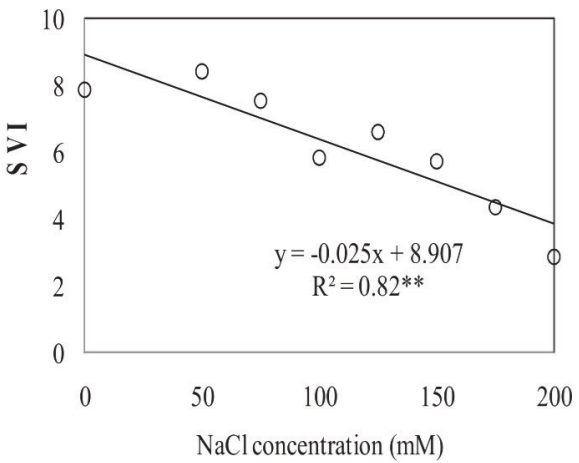

$\mathrm{NaCl}$ concentration $(\mathrm{mM})$

Fig.2. Cumulative germination percentage against time after experiment onset, in different $\mathrm{NaCl}$ concentrations $(\mathrm{mM})$
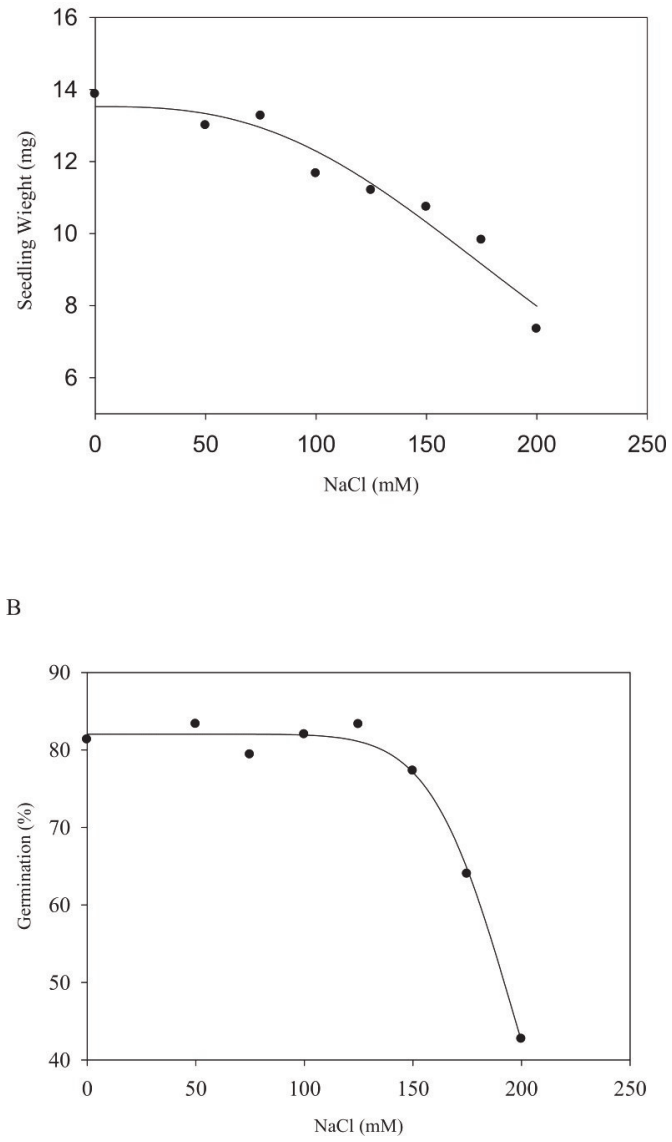

Fig.2. Cumulative germination percentage against time after experiment onset, in different $\mathrm{NaCl}$ concentrations $(\mathrm{mM})$ 
Curve slope and STI values for the seedling weight were obtained as 0.24 and 237.38 respectively and 0.54 and 231.9 for the seed germination percentage respectively (Table 4).

\section{DISCUSSION}

Germination percentage was significantly decreased by salt stress in milk thistle. Seed germination remained relatively unaffected by salinity up to 125 $\mathrm{mM} \mathrm{NaCl}$. Castroluna et al. (2014) evaluated some Medicago varieties' responses to salinity and reported that the germination percentage of Vedor variety between the control $(70 \%)$ and $50 \mathrm{mM}$ of $\mathrm{NaCl}$ or in moderately salinity $(77 \%)$ showed no significant differences. This result supported our observations and was confirmed in our results (Table 2).

In a research was reported that the lowest concentration of $\mathrm{NaCl}$ did not significantly affected radish seed germination (Kaymak et al., 2009). Furthermore, Ghavami and Ramin (2007) stated that seed germination was adversely affected under saline conditions. High concentrations of $\mathrm{NaCl}$ may have increased osmotic potential, meaning the seeds would have been unable to imbibe the water required for germination.

$\mathrm{NaCl}$ concentration effect on germination percentage up to $150 \mathrm{mM}$ was not significantly different from the control, while, germination time was delayed with increasing $\mathrm{NaCl}$ concentrations, which obviously occurred at higher concentrations than $50 \mathrm{mM}$ (Fig. 2). Although the germination percentage of seeds exposed to 50,100 and $125 \mathrm{mM}$ were close to seed germination in the control $(81.33 \%)$, germination in the control reached a maximum value after a MGT of $2.82 \mathrm{~d}$, while MGT for 50,100 and $125 \mathrm{mM}$ was delayed by $0.11,0.72$ and 0.9 $\mathrm{d}$, respectively, compared to the control (Table 2). These observations suggest that $50,75,100$ and $125 \mathrm{mM} \mathrm{NaCl}$ did not have a severe impact on the maximum seed germination percentage of milk thistle, while salt stress severity delayed germination time (MGT) (Fig. 4a). Fricke et al. (2006) reported that salt stress caused reduced cell turgor and depressed rates of root and leaf elongation, suggesting that $\mathrm{NaCl}$ concentrations acted primarily on water uptake. Furthermore, salt and osmotic stresses are responsible for both inhi-bition or delayed seed germination and seedling establish-ment (Almansouri et al., 2001). Therefore, seed germination time is affected by the severity of salinity stress.

Rajakumar (2013) showed that salt stress effect on the seed germination percentage of Oryza sativa up to $50 \mathrm{mM} \mathrm{NaCl}$ was the same to that of germination in the control, while a reduction in shoot and root length was observed at this salinity level. Kaya et al. (2003) reported that root growth in Carthamus tinctorius $\mathrm{L}$. was more sensitive and adversely affected compared to shoot growth under saline conditions, while our results in the case of $S$. marianum showed that shoot growth was more sensitive than root growth. This was the case particularly for those levels above $75 \mathrm{mM} \mathrm{NaCl}$ (Fig. 3a). According to Greenway and Munns (1980), after some time in $200 \mathrm{mM} \mathrm{NaCl}$, a salt-tolerant species such as sugar beet might have a reduction of $20 \%$ in dry weight, whereas a moderately tolerant species such as cotton might have a reduction of $60 \%$ in dry weight. 
Our results showed that dry weight had a reduction of $53 \%$ in $200 \mathrm{mM} \mathrm{NaCl}$ in relation to the control (Table 2); thus, this plant could be suggested as a species moderately tolerant to saline conditions.

Afzali et al. (2009) reported no significant difference in the root and shoot dry weights between the control and $80 \mathrm{mM} \mathrm{NaCl}$ treatments in chamomile; however, the adverse effect of $\mathrm{NaCl}$ was more pronounced for root biomass compared to shoot biomass. Rapid root extension enabled Trigonella seedlings to exploit moisture in dry habitats (Ramoliya et al., 2004), which is a mechanism for coping with salt stress. Thus, shoots were found to be more sensitive to salinity than roots. Similar to these observations, it has previously been reported that soil salinity suppresses shoot growth more than root growth (Ramoliya et al., 2004).

The highest significant differences were related to control and 150 to 200 $\mathrm{mM}$ concentrations (Table 2). It is possible that salt solution provided entry of the ions to the seeds, which may have been toxic to the embryo or the developing seedlings (Almodares et al., 2007). The inhibitory effect of $\mathrm{NaCl}$ on growth parameters could be attributed to the osmotic effect of $\mathrm{NaCl}$ (Salter et al., 2007).

The results of the present study revealed that salt stress inhibited seedling growth (root and shoot length, root and shoot dry weight); however, seedling weight was influenced more than seedling length. The same results regarding the reduction of seedling growth were reported by Jeannette et al. (2002) and Shannon et al. (2000). Mer et al. (2000) observed that by increasing salinity, plumule length decreased in wheat, barley, pea and cabbage. The researchers noted that the decrease in growth of young seedlings as a result of increasing salinity occur mostly because of a decrease in water absorption by radicle and by accumulation of salts solution in the cell. Additionally, in our study, we found that roots were less affected by salinity compared to shoots. This could suggest an advantage for milk thistle, in that their roots could create a more tolerant plant against water deficits occurring as a result of salinity stress.

It has been reported that the optimal growth of halophytic plants takes place in low salt concentrations (Esechie et al., 2002), while high salinity levels will cause a distinct decrease in plant growth. At present study seedling dry weight at the highest $\mathrm{NaCl}$ concentration $(200 \mathrm{mM})$ decreased $32.44 \%$ when compared to the control. Afzali et al. (2009) reported that the reduction in shoot dry weight in Matricaria chamomilla at the highest $\mathrm{NaCl}$ concentration $(190 \mathrm{mM})$ was about $32 \%$ when compared to the control.

While seed germination after $100 \mathrm{mM} \mathrm{NaCl}$ continued and was even more than the control at $125 \mathrm{mM}(83 \%)$, SVI showed that it was 1.28 times lower than the control at $125 \mathrm{mM} \mathrm{NaCl}$, and this index reduced at $200 \mathrm{mM} \mathrm{NaCl}$ to 2.91 times lower than the control. These results suggested that milk thistle seeds were able to germinate when exposed to fairly high salinity levels, but were not able to produce a healthy and normal seedling.

Linear regression was implemented to establish the relationship between salt stress and some traits in the seedling growth stage. Mavi et al. (2010) found a significant correlation between MGT and rate of emergence. They also reported significant correlations between the mean germination time (MGT) of cucur- 
bit seeds in the laboratory and mean emergence time (MET) and final emergence in the field. These results are in agreement with Rahman et al. (2008), who reported that ascending salt concentrations not only prevented the germination of seeds, but also extended germination time by delaying the starting of germination. Salt stress weakened the germination percentage and also prolonged the emergence of seeds in four vegetables species: Beta vulgaris, Brassica oleracea, Amaranthus paniculatus and Brassica campestris (Jamil et al., 2006). Jeannette et al. (2002) reported that a faster rate of germination allowed the emerging seedlings to accumulate more biomass relative to the control.

Results suggest that milk thistle has different behaviour in the germination stage relative to the seedling stage when is exposed to $\mathrm{NaCl}$. The results confirmed that milk thistle was more tolerant in the seedling stage due to a lower curve slop and higher STI. Seydi (2003) stated that the salt tolerance index is considered a reliable criterion for salt tolerance. Plant responses to salt and drought are closely related and the mechanisms of their reactions overlap (Zhu 2011). Since salt stress is usually associated with drought stress, an approach for establishing a suitable time selection for integrated irrigation in water limited areas should be considered.

\section{CONCLUSION}

By increasing $\mathrm{NaCl}$ concentration, milk thistle germination was prolonged and seed germination percentage decreased. Additionally, root and shoot length and weight were reduced by enhancing salt severity. Our results showed that when salinity varied from 50 to $150 \mathrm{mM}$, germination (\%), seedling length and weight reduced, MGT increased (Table 2). The findings suggest that seed germination continued even in the highest salinity concentration levels; however, a drastic decrease in SVI and an increase in MGT will lead to a weak emerging seedling.

The effect of salt concentration on shoot weight was higher than on root weight. In other words, milk thistle roots were able to restore and grow under moderate salinity conditions such as those shown in this experiment, so that these changes may reflect an adaptive advantage for the plant in terms of acquiring limited resources. Overall the results indicated that Silybum marianum as a valuable medicinal plant could be considered as a moderately tolerant to salinity during seedling growth. Recognizing this may help breeders to produce a plant with better adaption abilities.

Understanding the ways in which plants can tolerate salt stress conditions is necessary for growing and developing plants on marginal agricultural lands that are unproductive.

\section{REFERENCES}

Ahmadian, M. ,R. Kalvandi and F. Zand. 2012. Comparison of solute-specific effects on seed germination characteristics of SM seed (Silybum marianum) at the same osmotic potential under salinity and drought stress conditions. Annals Biol. Res. 3 (8): 4145-4153. 
Afzali, S.F. ,H. Shaiatmadari and M.A. Hajabbasi. 2009. Sodium Chloride Effects on Seed Germination, Growth and Ion Concentration in Chamomile (Matricaria Chamomilla). Iran Agri. Res. 28 )2( .118-107: (In Persian with english abstract)

Ali, R.M. ,H.M. Abbas and R.K. Kamal. 2007. The effects of treatment with polyamines on dry matter, oil and flavonoid contents in salinity stressed chamomile and sweet marjoram. Plant, Soil Environ. 53:52943.

Almansouri, M. ,J.M. Kinet and S. Lutts. 2001. Effect of salt and osmotic stresses on germination in durum wheat (Triticum durum Desf.). Plant and Soil, 231: 243-254.

Almodares, A. ,M.R. Hadi and B. Dosti. 2007. Effects of salt stress on germination percentage and seedling growth in sweet sorghum cultivars. J. Biol. Sci. 7 (8): 1492-1495.

Ashraf, M. and M.R. Foolad. 2005. Pre-sowing seed treatment-a shotgun approach to improve germination growth and crop yield under saline and none-saline conditions. Adv. Agro. 88, 223-271.

Baatour, O.R. ,W. Kaddour, A. Wannes, M. Lachaal and B. Marzouk. 2010. Salt effects on the growth, mineral nutrition, essential oil yield and composition of marjoram (Origanum majorana). Acta Physiol. Plant. 32:45-51.

Belaqziz, R., A. Romane and A. Abbad. 2009. Salt stress effects on germination, growth and essential oil content of an endemic thyme species in Morocco (Thymus maroccanus Ball.). J. appl. Sci. Res. 5 (7): 858-63.

Castroluna, A., O.M. Ruiz, and A.M. Quiroga and H.E. Pedranzani. 2014. Effects of salinity and drought stress on germination, biomass and growth in three varieties of Medicago sativa L. Avances en Investigación Agropecuaria, 18 (1): 39-50.

Chaudhary, S.A., K.V. Gadhvi and A.B. Chaudhary. 2010. Comprehensive review on world herb trade and most utilized medicinal plant. Int. J. Appl. Biol. Pharm. Tech. 510 - 517.

Chauhan, B.S., G. Gill and C. Preston. 2006. Factors affecting seed germination of annual sow thistle (Sonchus oleraceus) in southern Australia. Weed Sci. 54: 854-860.

Edward, A.K. and M.A. Bison. 1996. Plasma membrane Na+ transport in salt tolerant charophyte. Plant Physiol. 111: 1191-1197.

Ellis, R.A. and E.H. Roberts. 1981. The quantification of aging and survival in orthodox seeds. Seed Sci. Tech.9: 373-409.

Elouaer, M.A. and C. Hannachi. 2012. Seed priming to improve germination and seedling growth of safflower (Carthamus tinctorius) under salt stress. EurAs. J. BioSci. 6: 76-84.

Esechie, H.A., V. Rodriguez and H.S. Al-Asmi. 2002. Effect of sodium chloride salinity on cation equilibration in alfalfa (Medicago sativa L.). Crop Res. 23:253-258.

Fricke, W., G. Akhiyarova, W. Wei, E. Alexanderssn, A. Miller, P.O. Kjellbom, A. Richardson, T. Wojciechowski, L. Schreiber, D. Veselov, G. Kudoyarova and V. Volkar. 2006. The short term growth responses to salt of the developing barley leaf. J. Exp. Bot. 57 (5): 1079-1095.

Ghaderi-Far, F., V. Akbarpour, F. Khavari and A. Ehteshamnia. 2012. Determination of salinity tolerance threshold in six medicinal plants. J. Plant Pro. 18 (4): 15-24.

Ghavami N., Ramin A.A. (2007) Salinity and temperature effect on seed germination of milk thistle. Commun. Soil Sci. Plant. 38 (19/20): 2681-2691.

Ghavami, N. and A.A. Ramin. 2008. Grain yield and active substances of milk thistle as affected by soil salinity. Commun. Soil Sci. Plant. 39 (17 \& 18): 2608-18.

Graifenberg, A., M. Lipucci di Paola, L. Giustiniani and O. Temperini. 1993. Yield and growth of globe artichoke under saline-sodic conditions. Hort. Sci. 28: 791-793.

Greenway H, Munns R (1980). Mechanisms of salt tolerance in nonhalophytes. Annu. Rev. Plant Phys. 31: $149-190$.

Islam, A.K., N. Anuar and Z. Yaakob. 2009. Effect of genotypes and pre-sowing treatments on seed germination behavior of Jatropha. Asian J. Plant Sci. 8:433-439.

Jamil, M., D.B. Lee, K.Y. Jung, S.C. Lee and E.S. Rha. 2006. Effect of salt (NaCl) stress on germination and early seedling growth of four vegetables species. J. Central Eur. Agri.7 (2): 273-282.

Jeannette S., R. Craig and J.P. Lynch. 2002. Salinity tolerance of Phaseolus species during germination and early seedling growth. Crop Sci. 42: 1584-1594.

Kamkar, B., M. Kafi and M. Nassiri Mahallati. 2004. Determination of the most sensitive developmental period of wheat (Triticum aestivum) to salt stress to optimize saline water utilization.4th International Crop Science Congress. Karaj, Iran, 1-6.

Kaya, M.D., A. Ipek, A. Ozturk. 2003. Effects of different soil salinity levels on germination and seedling growth of safflower (Carthamus tinctoriusL.). Turk. J. Agri. Forestry. 27: 221-227.

Kaymak, H.C., I. Güvenç, F. Yaral and M.F. Dönmez. 2009. The effects of bio-priming with PGPR on germination of radish (Raphanus sativus L.) seeds under saline conditions. Turk. J. Agri. Forestry. 33: $173-$ 179.

Khan, H.A., C.M. Ayub, M.A. Pervez, R.M. Billal, M.A. Shahid and K. Ziaf. 2009. Effect of seed priming with $\mathrm{NaCl}$ on salinity tolerance of hot pepper (Capsicum annuumL.) at seedling stage. Soil and Environ. 28: 81-87.

Luper, S. 1998. A review of plants used in the treatment of liver diseases: Part 1. Alternative Med. Rev. 3: 410 -21 . 
Maas, E.V. and G.J. Hoffmann. 1977. Crop salt tolerance-current assessment. J. Irr. Drain. Div-ASCE. 103 (IR2): 115-134.

Mavi, K., I. Demir and S. Matthews. 2010. Mean germination time estimates the relative emergence of seed lots of three cucurbit crops under stress conditions. Seed Sci. Tech. 38, 14-25.

Mer, R.K., D.H. Prajith and A.N. Pandya. 2000. Growth of young plants of Hourdeum vulgare, Triticum aestivum, Cicer arietium and Brassica juncea. J. Agron. Crop Sci. 185: 209-217.

Miceli, A., A. Moncada, F. D'Anna. 2003. Effect of water salinity on seeds-germination of Ocimum basilicumL., Eruca sativa L. and Petroselinum hortense Hoffm. Acta Horticulturae, 609: 365-70.

Pradhan, S.C. and C. Girish, 2006. Hepatoprotective herbal drug, silymarin from experimental pharmacology to clinical medicine. Indian J. Med. Res. 124 (5): 491-504.

Qureshi, M., M. Israr, M. Abdin and M. Iqbal. 2005. Responses of Artemisia annua L. to lead and saltinduced oxidative stress. Environ. Exp.Bot. 53:185-193.

Rahman, M., U.A. Soomro, M. Zahoor-ul-Haq and S. Gul. 2008. Effects of $\mathrm{NaCl}$ salinity on wheat (Triticum aestivum L.) cultivars. World J. Agri. Sci. 4 (3): 398-403.

Rajakumar, R. 2013. A study on effect of salt stress in the seed germination and biochemical parameters of rice (Oryza sativa L.) under in vitro condition. Asian J. Plant Sci. Res. 3 (6): 20-25.

Ramin, A.A. 2005. Effects of salinity and temperature on germination and seedling establishment of sweet basil (Ocimum basilicumL.). J. Herbs, Spices \& Med. Plants, 11(4):81-90.

Ramoliya, P.J., H.M. Patel and A.N. Pandey. 2004. Effect of salinization of soil on growth and macro and micronutrient accumulation in seedlings of Acacia catech $u$ (Mimosaceae). Ann. Appl. Biol. 144: 321-332.

Razmjoo, K., P. Heydarizadeh and M.R. Sabzalian. 2008. Effect of Salinity and Drought Stresses on Growth Parameters and Essential oil Content of Matricaria chamomila. Int. J. Agri. Biol. 10: 451-4.

Salter, J., K. Morris, P.C.E. Bailey and P.I. Boon. 2007. Interactive effects of salinity and water depth on the growth of Melaleuca ericifolia Sm. (Swamp paper bark) seedlings. Aquat. Bot. 86: 213-222.

Seydi, A.B. 2003. Determination of the salt tolerance of some barley genotypes and the characteristics affecting tolerance. Turk. J. Agri. 27, 253-260.

Shannon, M.C., C.M. Grieve, S.M. Lesch and J.H. Draper. 2000. Analysis of salt tolerance in nine leafy vegetables irrigated with saline drainage water. J. Am. Soc. Hortic. Sci. 125: 658-664.

Sivritepe, H.O. and N. Sivritepe. 2007. $\mathrm{NaCl}$ priming affects salt tolerance of onion (Allium cepa L.) seedlings. Acta Hortic. 729: 157-161.

Sosa, L., A. Llanes, H. Reinoso, M. Reginato and V. Luna. 2005. Osmotic and specific ion effect on the germination of Prospis strombulifera. Ann. Bot. 96: 261-7.

Steppuhn, H., M.T. Van Genuchten and C.M. Grieve. 2005. Root-zone salinity. II. Indices for tolerance in agricultural crops. Crop Sci. 45: 221-232.

Siadat, H., M. Bybordi and M.J. Malakouti. 1997. Salt affected soils of Iran: A country report. International symposium on sustainable management of salt affected soils in the arid ecosystem. University of Ain Shams Press, Cario. Egypt.

Tanveer, A., M. Tasneem, A. Khaliq, M.M. Javaid and M.N. Chaudhry. 2013. Influence of seed size and ecological factors on the germination and emergence of field bindweed (Convolvulus arvensis). Planta Daninha. 31 (1): 39-51.

Torbaghan, M.E. 2012. Effect of salt stress on germination and some growth parameters of marigold (Calendula officinalis L.). Plant Sci. J. 1 (1): 7-19.

Yildirim, E., H. Karlidag and A. Dursun. 2011. Salt tolerance of Physalis during germination and seedling growth. Pakistan. J. Bot. 43 (6): 2673-2676.

Zhu, J.K. 2002. Salt and Drought Stress Signal Transduction in Plants. Ann. Rev. Plant Biol. 53: 247-273. 